\title{
THE AMENDING PROCESS IN CANADA AND THE UNITED STATES: A COMPARATIVE PERSPECTIVE
}

\author{
Walter Dellinger*
}

For 115 years the basic written constitution of Canada had been a statute of the United Kingdom Parliament, the British North America Act of 1867 (BNA) and its amendments. ${ }^{1}$ On April 17, 1982, Queen Elizabeth II brought these acts home to Canada in a ceremony celebrating the recent passage by the United Kingdom Parliament of the Canada Act of 1982. ${ }^{2}$ The Canada Act was the final amendment by the Parliament in London of the BNA Act; this basic document will henceforth be a wholly domestic Canadian law, amendable by Canada alone without the unseemly necessity of petition to the parliament of a foreign government.

Passed two years after the American Civil War, the British North America Act united the British colonies of Canada (Ontario and Quebec), Nova Scotia, and New Brunswick into a new federated nation. The BNA Act provided the basic constitution of Canada, allocating authority between the federal and provincial governments. As a statute of the United Kingdom, however, it could be changed only by the Parliament in London. In practice amendments have been made upon (and only upon) formal request by the government of Canada. ${ }^{3}$

For half a century, efforts have been made to "patriate" the Canadian Constitution: that is, to terminate the formal power of the United Kingdom Parliament to change the BNA and to make its provisions a part of the law of Canada, amendable by processes wholly Canadian. And for half a century these efforts were unsuccessful, for the Canadian federal government and the governments of the ten Canadian provinces were unable to agree upon a formula for amending the constitution once it became part of Canadian law and no longer subject to revision by the United Kingdom Parliament.

Finally, in November 1981, after months of intense controversy, the Canadian federal government and nine of the ten provinces reached agreement on a future amending process. ${ }^{5}$ In spite of the objections of Quebec, the Parliament of the

Copyright $\odot 1983$ by Law and Contemporary Problems

* Professor of Law, Duke University.

I wish to thank my colleague Donald Horowitz for his helpful comments and Kathryn Battuello and Teresa Reichert for their assistance on this article.

1. British North America Act, 1867,30 \& 31 Vict., ch. 3.

2. Canada Act, 1982, ch. 11.

3. See P. Hogg, Constitutional Law of Canada 18-20 (1977).

4. See generally G. Favreau, The Amendment of the Constitution of Canada ch. III (1965) (discussing the federal-provincial conferences and meetings of 1927, 1935-36, 1950, 1960-61, and 1964).

5. Montreal Gazette, Nov. 6, 1981, at 1, col. 5. 
United Kingdom responded to a "Joint Address to the Queen" from the Canadian Senate and House of Commons by enacting, in March 1982, the Canada Act. ${ }^{6}$ This final London amendment to the BNA Act converted it into the Constitution Act of $\mathrm{Canada}^{7}$ and added the agreed upon formula for effecting future constitutional amendments through Canadian procedures. ${ }^{8}$

That the dispute over a future Canadian amendment formula was the critical issue preventing for so long the patriation of the Canadian Constitution should not be surprising. In a federal system of powers divided between the central government and provincial (or state) governments, the two most critical issues are the initial allocation of powers between the two levels of government, and the location of power to change that allocation in the future. ${ }^{9}$ It may indeed be said that legal "sovereignty" resides in that combination of bodies with power to effectuate changes in the fundamental law. The amending power can alter whatever delicate balance has been achieved in constructing a federal system. Thus the amending power is the most delicate of issues.

Once a genuine consensus is achieved on the proper relationship between central and provincial authority, agreement on an amendment process follows naturally, as it did in the United States in 1787. ${ }^{10}$ Where there is no agreement on the proper allocation of authority, or (more fundamentally) no agreement on the desired level of unity within the society, as has been the case in Canada, agreement on a wholly satisfactory amendment process becomes impossible. Though an amendment formula may seem to be a relatively small aspect of a constitutional system, it is in fact the fulcrum of future power. Debates over the allocation of authority for future constitutional change become, as they did in Canada, debates over the desired level of unity in the society. Until a substantial consensus is reached on the underlying questions of nationhood, no satisfactory agreement can be reached on a process of amendment.

Why did it take half a century of struggle to agree upon an amendment formula for Canada? And how successful was the effort? This comparative look at the American and Canadian amendment processes, their evolution, and prospects, will attempt to shed some light on these questions. ${ }^{11}$

\section{The Evolution of the American Amendment Process}

The coming together of the American colonies into a single nation was more difficult than we can easily now imagine. John Adams, at the Continental Congress in 1775, spoke of "[f]ifty gentlemen meeting together all strangers, . . . not

6. Canada Act, 1982, ch. 11.

7. Constitution Act, 1982, pt. 7, $\$ 52(2)$, Sched. B (Can.).

8. Id. pt. 5 .

9. Pearson, Introduction to G. FAVREAU, supra note 4 , at vii.

10. See infra pp. 286-87.

11. Since this paper was delivered to the Duke-McGill Conference on April 27, 1982, at least three books have been published concerning the reformed Canadian Constitution. See generally E. MCWHINNEY, Canada and the Constitution 1979-1982 (1982); D. Milne, The New Canadian Constitution (1982); and P. Hogg, Canada ACt 1982 Annotated (1982). 
acquainted with each other's language, ideas, views, designs. They are therefore jealous of each other-fearful, timid, skittish."12 While to us they stand at the beginning, initiating a history, Garry Wills notes that "they saw themselves as defenders of a history accomplished; taking risks that might end, rather than launch, a noble experiment."13 They came as representatives of legislative assem-. blies a century old; indeed, the Virginia House of Burgesses had held an unbroken sequence of sessions for over one hundred and fifty years. The colonies were more trading rivals than partners. ${ }^{14}$ The physical distances were vast, and land travel between colonies was an arduous undertaking. None of the Massachusetts delegates had ever seen Philadelphia. ${ }^{15}$

The American colonies fought the war as allies, not as a union. At war's end they confederated as thirteen governments under Articles of Confederation, each retaining its "sovereignty, freedom, and independence" 16 except as expressly delegated to a Congress of limited authority, in which each state voted as a state and cast a single vote. ${ }^{17}$

Of the many problems which beset this Confederation, ("We are fast verging to anarchy and confusion," wrote Washington to Madison) ${ }^{18}$ the overriding constitutional difficulty was that no alteration designed to remedy its other defects could be made without the unanimous consent of all the parties to the Articles of Confederation. ${ }^{19}$ And unanimity on proposed amendments was impossible to achieve.

Change could thus be made only under a new constitutional order. Even though the instructions to the Constitutional Convention in Philadelphia were limited to proposing alterations in the Articles of Confederation, it was apparent from the outset that nothing less than a wholly new constitution would be proposed. ${ }^{20}$ Since unanimity was required for alterations in the Articles of Confederation, and unanimity could not be achieved, a new Constitution was to take effect when ratified by nine of the thirteen states. It was understood, however, that no state could be forced into the newly constituted nation without its consent. The new Constitution would take effect when ratified by nine states-but only as a union of those states which chose to ratify. ${ }^{21}$

From the outset of the Philadelphia Convention, the delegates recognized the

12. John Adams, Remarks at the Continental Congress (1775), quoted in G. WiLLS, INVENTING AMERICA 34 (1979).

13. G. Wills, INVENTING AMERiCA 38 (1979).

14. 2 R. Middlekauff, The Glorious Cause 27-28 (1982).

15. G. WILLS, supra note 13 , at 46 .

16. Articles of Confederation art. II (1778).

17. Id. art. V.

18. Letter of George Washington to James Madison, November 5, 1776, copy on file, Perkins Library, Duke University.

19. Articles of Confederation art. XIII (1778).

20. The Virginia Resolutions, introduced by Edmund Randolph on the third day of the Constitutional Convention, proposed sweeping changes. See 1 THE ReCORDS OF THE FEDERAL CoNVENTION OF 1787, at 20-23 (M. Farrand ed. 1937) [hereinafter cited as 1 FARRAND].

21. "The Ratification of the Conventions of nine States, shall be sufficient for the Establishment of this Constitution between the States so ratifying the Same." U.S. CONST. art. VII. 
need to create a process by which future revision would be a genuine possibility. ${ }^{22}$ The amendment prosess represented, in a sense, the domestication and taming of the right to revolution which had been proclaimed by the colonists. The early state constitutions legitimated the right of revolution by proclaiming the right to "reform the old or establish a new government." (Maryland, 1776). ${ }^{23}$ Most early state constitutions did not, however, contain any definite procedures by which reform or reformation could be accomplished. As Judge Jameson noted,

[T] he doctrine of the Revolution, that governments were founded by the people, and could be amended by them as they should think fit, was erroneously understood to warrant tumultuous assemblages of citizens, without legal authority, to dictate to the government not only its current policy, but amendments of the fundamental law. ${ }^{24}$

The inclusion of specific amendment procedures can thus be seen as part of the conservative thrust of much of the work of the Convention. The inclusion of a specific amendment procedure emphasized that changes of fundamental law were henceforth to be made only in accordance with modes sanctioned by the document itself, and thus served to confine the right to revolution within prescribed legal procedures.

Throughout the summer of 1787 , the delegates at the Philadelphia Convention constructed the basic framework of American federalism. Only in the closing days of the Convention-after the difficult task of achieving consensus on the delicate balance of state and national power had been completed-was agreement reached on an amendment formula. ${ }^{25}$

The Convention did not find it difficult to agree upon the method for ratifying any proposed amendments: after considering a requirement for unanimous ratification, and one that would have required ratification by two-thirds of the states, the Convention settled upon three-fourths of the states as the proper number to agree to any proposed amendment. ${ }^{26}$ The more critical question was whether the national Congress should be given the exclusive authority to propose amendments. And if there should be some method free of congressional control for proposing amendments for state ratification, what should that method be?

Unlike the Canadian experience, in which every suggested amendment formula required the assent of the national parliament for all amendments, the American framers found it particularly difficult to decide whether Congress should have the power to veto amendments desired by the states. The Virginia Resolutions, presented at the outset of the Convention by John Randolph, stated "that provision ought to be made for the amendment of the Articles of Union whensoever it shall seem necessary, and that the assent of the National Legislature ought

22. Section 13 of the Virginia Resolutions provided that "provision ought to be made for the amendment of the Articles of Union whensoever it shall seem necessary . . . ." 1 FARRAND supro note 20 , at 22.

23. 3 F. Thorpe, The Federal and State Constitutions, Colonial Charters, and Other ORGaNic LaWS (1909).

24. J. Jameson, Constitutional Conventions 548 (4th ed. Chicago 1887) (1st ed. n.p. 1866).

25. For a discussion of the evolution of Article $V$ at the Constitutional Convention see Dellinger, The Recurring Question of the "Limited" Constitutional Convention, 88 YALE L.J. 1623, 1624-1630 (1979).

26. 2 The Records of the Federal Convention of 1787, at 555 (M. Farrand ed. 1937) [hereinafter cited as 2 FARRAND]. 
not be required thereto." 27

Midway through its deliberations, however, the Convention considered giving to Congress the sole power to propose amendments to the states for ratification. This was not acceptable to Mason of Virginia who had earlier stated that "[i]t would be improper to require the consent of the Natl. Legislature, because they may abuse their power, and refuse their consent on that very account."28 One tentative proposal would have given Congress the authority to propose amendments whenever (1) Congress thought amendment necessary or (2) whenever twothirds of the states thought amendment necessary. ${ }^{29}$ Even this version was objectionable to Mason who feared that

As the proposing of amendments is in both modes to depend, in the first immediately, and in the second, ultimately, on Congress, no amendments of the proper kind would ever be obtained by the people, if the Government should become oppressive, as he verily believed would be the case. ${ }^{30}$

Some delegates believed the proposal avoided this difficulty by permitting twothirds of the states actually to draft a proposed amendment which Congress would be required automatically to submit to the state legislatures for ratification. ${ }^{31}$ Such a system would have allowed proposed amendments to be made by a process of state legislative initiation and state ratification which would not require any national forum to approve the substance of the change. This was unsatisfactory to nationalists such as Alexander Hamilton who expressed the concern that " $t]$ he State Legislatures will not apply for alterations but with a view to increase their own powers - . . . ."32 Various framers thus feared lodging exclusive power over amendment proposals in Congress. Others were apprehensive about any process by which the state legislatures could both propose and ratify amendments without the approval of a body designed to reflect the national interest.

The solution to this dilemma was one of the pragmatic compromises that mark the Constitution. In addition to providing that amendments may be proposed by Congress, the final version also required Congress to summon a Constitutional Convention whenever two-thirds of the state legislatures applied for one. Such a convention would be, like Congress, a deliberative body capable of assessing, from a national perspective, the need for constitutional change and drafting proposals for submission to the states for ratification. At the same time it would not be Congress, and therefore would not pose the threat of legislative self-interest blocking needed reform of Congress itself.

Having agreed upon alternative methods for proposing amendments (Congress, or a national convention summoned at the request of two-thirds of the states) and alternative methods for ascertaining the assent of three-fourths of the states (ratification by state legislatures or by conventions in each state) the Convention had completed its work on Article V, which read, in its final form:

27. 1 FARRAND, supra note 20 , at 22 .

28. Id. at 203.

29. 2 FARRAND, supra note 26 , at 559 .

30. Id. at 629 .

31. Id at 629-30.

32. Id at 558 . 
The Congress, whenever two thirds of both Houses shall deem it necessary, shall propose Amendments to this Constitution, or, on the Application of the Legislatures of two thirds of the several States, shall call a Convention for proposing Amendments, which, in either Case, shall be valid to all Intents and Purposes, as Part of this Constitution, when ratified by the Legislatures of three fourths of the several States, or by Conventions in three fourths thereof, as the one or the other Mode of Ratification may be proposed by the Congress

A detailed commentary on Article $\mathrm{V}$ will follow later in this article, allowing for a comparison with the Canadian procedures to be described below. Nevertheless, it is worth noting here a few of the more salient points about the American amendment article. Nowhere in the American Constitution (except perhaps in the original provision for selection of two United States Senators by the legislature of each state) ${ }^{34}$ is its federal character more pronounced. Each state counts as one in the amendment process. Unlike the presidential selection process, ${ }^{35}$ Article $\mathrm{V}$ does not provide for the "votes" of each state to be weighted by population. Nor is there any requirement that those states approving an amendment contain even a bare majority of the national population.

What is critical is approval by the designated body (state legislature or state convention) in the requisite number of states - not the degree of national popular support. How much popular support a proposed amendment needs varies enormously depending upon whether it is supported or opposed principally in small or large states. An amendment opposed by the 12 smallest states containing (1980) 3.8 percent of the national population will not be valid unless it is approved by 38 states with 96 percent of the national population. On the other hand, an amendment favored by the 38 less populous states would be ratified despite the opposition of states with nearly 60 percent of the national population. Since a constitutional convention is to be summoned at the request of two-thirds of the states, a convention can be called at the instance of states with 32 percent of the national population (the 34 smallest) to propose amendments which will be effective if ratified by states with 41 percent of the population ( 38 smallest). ${ }^{36}$

The proposed Equal Rights Amendment, on the other hand, has been ratified by states with 70 percent of the national population. If ratified by the two next most likely states, Illinois and Florida, it would have been ratified by states with 80 percent of the national population and still not be a part of the Constitution. Thus, populations of states needed to approve a proposed constitutional change can vary (in 1980) from 41 percent to 96 percent depending upon whether the proposal is supported by smaller or larger states.

These are factors of which the framers of Article $V$ were not unaware. Population variations in 1787 were similar; some amendments could be ratified with the

33. U.S. Const. art. V.

34. Id. art I, $\S 3$, cl. 1 .

35. Id. art II, $\S 1, \mathrm{cl} .2$.

36. U.S. Dept. of Commerce, Bureau of the Census, Population Profile of the United States: 1980, Current Population Reports, Population Characteristics Series P-20, No. 363, issued June 1981 Table 6.

In contrast, the Canadian amending formula requires that the ratifying provinces contain at least $50 \%$ of the national population in order for an amendment to be ratified. 
support of states with less than half the population, and others fail even though supported by states with over 90 percent of the population. ${ }^{37}$ These figures reflect an inevitable conflict between the underlying principles of federalism and democracy (in the sense of control by national popular majority). The important federal principle embodied in Article $V$ is that the assent of each state is fully as significant as that of any other state. A citizen of Delaware or Utah thus has a far greater voice in the amendment process than one in California or New York. The equality relevant to the process of amendment under Article $\mathrm{V}$ is the equality of states in a federal union, and not that of individual citizens.

The second salient characteristic of Article $\mathrm{V}$ is the attempt to provide mechanisms of constitutional change free of the control of existing governmental institutions. Although every amendment to date has been proposed by the United States Congress, and every successful amendment but one ratified by state legislatures, the framers included alternative mechanisms both for proposing and for ratifying amendments. As noted above, amendments can be proposed by a national constitutional convention free of congressional control. To be sure, such a convention can be held only upon the petition of state legislatures; once properly convened, however, such a convention can, in the view of many scholars, determine its own agenda and submit for ratification whatever amendments it deems appropriate. ${ }^{38}$

The framers provided as well for a method of ratification that would allow amendments to be made over the opposition of state legislatures. By giving to Congress the power to submit proposed amendments to conventions in each state, rather than to the state legislatures, the possibility of a reform which restricts the power of existing state legislatures is preserved.

The "convention of the people" was a familiar device in the eighteenth century. ${ }^{39}$ It now seems archaic, and the use of either a national convention for proposing amendments or state conventions for ratification are at present fraught with difficulties and uncertainties too complex for full discussion here. The convention device was nonetheless an imaginative effort to address a universal problem of constitutional amendment procedures: how to provide the means of reforming existing governmental institutions, when the only institutions readily

37. One amendment proposed by Congress has failed to become part of the Constitution even though ratified by states with more than three-fourths of the national population. The first amendment proposed by Congress, as part of the package which was to become the Bill of Rights, would have changed the representation in Congress so as to provide a guarantee of more representatives in proportion to population than was the case under the original Constitution. This apportionment amendment was ratified by ten states -all but Delaware, Massachusetts, Georgia, and Connecticut. The ratifying states contained $79.6 \%$ of the national population. W. Livingston, FEDERAlism and Constitutional Change 234 (1956). Thus an amendment favored by two-thirds of both Houses of Congress, and states with nearly $80 \%$ of the population, failed for lack of the required number of state ratifications.

In 1790 , the ten larger states had $92.7 \%$ of the population; the four smallest states which could preclude amendments from being ratified, had only $7.3 \%$ of the population. See HEADS OF FAMILIES, FIRST CENSUS OF THE UNITED STATES: 1790 (Government Printing Office, 1908).

38. See Dellinger, supra note 25; Dellinger, Who Controls A Constitutional Convention? - A Response, 1979 Duke L.J. 999. For the contrary view, see Van Alstyne, Does Article $V$ Restrict the States to Calling Unlimited Conventions Only? - A Letter to a Colleague, 1978 Duke L.J. 1295; Van Alstyne, The Limited Constitutional Convention - The Recuming Answer, 1979 DUKE L.J. 985. (1969).

39. See genetally G. WOOD, The CREation OF THE AMERICAN Republic, 1776-1787, at 306-43 
available for proposing and ratifying amendments are those already in existence, and possibly in need of reform themselves. (As shall be seen, this is a difficulty for the new Canadian amendment process as well.) ${ }^{40}$

Having settled upon a future amendment formula, the Philadelphia delegates were faced with a more immediate problem of constitutional revision: how to bring into being the proposed constitution itself. The Convention, summoned only to propose changes in the Articles of Confederation, had outrun its limited mandate. The amendment process under the articles, requiring unanimous consent of all 13 states, did not promise to be successful. In seeking legitimacy for the new constitutional system, the delegates felt considerable discomfort about the "revolutionary" action of discarding an old order in a manner not sanctioned by the existing Articles. Elbridge Gerry of Massachusetts urged "the indecency and pernicious tendency of dissolving in so slight a manner, the solemn obligations of the articles of confederation" 41 and suggested that if nine out of thirteen can dissolve the existing compact, "[s]ix out of nine will be just as able to dissolve the new one hereafter." 42 Alexander Hamilton also expressed misgivings about allowing nine states "to institute a new Government on the ruins of the existing one." 43 They nonetheless decided not to submit the Constitution to the existing Congress for approval or disapproval, but merely to lay before Congress the draft Constitution, and to provide that the Constitution would take effect, upon the ratification of nine states, in those states which chose to ratify. ${ }^{44}$ In a critical decision, it was determined that the Constitution would be placed for ratification not before the existing legislatures of the states, but before conventions of delegates chosen by the people for the express purpose of ratification or rejection. ${ }^{45}$ In this way, the new Constitution would not falter at the hands of state legislative bodies whose power was being significantly diminished by the proposed document.

The ratification of the proposed constitution was nonetheless a difficult and intensely contested process; the outcome was precariously close in the essential states of Virginia ${ }^{46}$ and New York. ${ }^{47}$ Critical to the success of ratification was the proponents' campaign promise to make early resort to the new amendment process to add a Bill of Rights to the original document. ${ }^{48}$

In spite of the close division over its adoption, the Constitution has provided a stable structure of government for nearly two centuries. The Article $\mathrm{V}$ revision process has contributed to that stability, permitting twenty-six amendments to be made in response to changing conceptions of public good and private rights. The

\footnotetext{
40. See infra p. 300 .

41. 2 FARRAND, supra note 26 , at 561 .

42. Id.

43. Id. at 560 .

44. Id. at $562-63$.

45. Id. at 475-78.

46. The Virginia Convention voted for ratification by a vote of 89-79. 3 THE DEBATES IN THE SEVeral State Conventions on the adoption of the Federal Constitution, as Recommended by the General Convention at Philadelphia in 1787, at 654-55 (J. Elliot 2d ed. 1937) [hereinafter cited as Elliot's Debates].

47. The New York Convention voted to ratify by a vote of 30-27. 2 ElLIOT'S Debates 413.

48. See generally R. Rutland, The Birth of the Bill of Rights 159-89 (1955).
} 
Article $\mathrm{V}$ amendment process is now itself a subject of renewed controversy. After reviewing the evolution of the new Canadian amendment process, this paper will conclude with a comparative assessment of the Canadian and American approaches to constitutional revision.

II

\section{The Evolution of the Canadian Amendment Process}

The passage in 1867 of the BNA Act by the Parliament in London served to unite several former colonies into a dominion under the name of Canada. It did not, however, create a truly independent nation. Canada was to a significant extent still a British colony, subordinate to London in foreign affairs and subject still to the power of the imperial Parliament to enact statutes controlling in Canada. The evolution of Canada into an independent nation has been a gradual one.

Although the BNA Act conferred a substantial measure of authority for selfgovernment on Canada, established the central and provincial governments and defined their respective authorities, it did not include any provision by which Canadian authorities could amend those allocations of power or make other changes in the BNA Act without recourse to the United Kingdom Parliament.

The reality of independence for Canada was achieved over the ensuing years. A signal step was the enactment by the U.K. Parliament of the Statute of Westminster in 1931.49 The statute provided that hereafter no statute of the United Kingdom would extend to a dominion "unless it is expressly declared in that Act that that Dominion has requested, and consented to the enactment thereof." 50 The Act further granted to each dominion the power to repeal or revise any imperial statutes which had previously been passed and applied to the dominion. ${ }^{51}$

Had the Statute of Westminster said no more, the federal Canadian Parliament could have revised, on its own authority, the provisions of the BNA Act, without the consent or participation of the Canadian provinces. The division of authority between the central and provincial governments, established by the BNA Act, could thus have been altered at the will of the federal government. The Canadian provincial governments insisted upon the inclusion of a clause protecting them from this threat. The result was a provision preventing any alteration by Canada alone of the BNA Act. ${ }^{52}$

Canada was thus left, as it had been since 1867 , with no means for altering its

49. Statute of Westminster, 1931, 22 Geo. 5, ch. 4 .

50. Id. $\$ 4$.

51. No law and no provision of any law made after the commencement of this Act by the Parliament of a Dominion shall be void or inoperative on the ground that it is repugnant to the law of England, or to the provisions of any existing or future Act of Parliament of the United Kingdom, or to any order, rule or regulation made under any such Act, and the powers of the Parliament of a Dominion shall include the power to repeal or amend any such Act, order, rule or regulation in so far as the same is Id. $\S 2(2)$ part of the law of the Dominion.

52. Id. $\S 7(1)$ provides that "Nothing in this Act shall be deemed to apply to the repeal, amendment or alteration of the British North America Acts, 1867 to 1930, or any order, rule or regulation made thereunder." 
basic constitutional document except through enactments by the United Kingdom Parliament. Subsequent revision of the BNA Act by the imperial Parliament in 1949 granted to the Canadian House of Commons and Senate authority to make constitutional changes affecting only the federal government. ${ }^{53}$ Changes affecting the distribution of powers between the federal and provincial governments continued to be possible only by action of the imperial Parliament. The convention was clearly established, however, that the United Kingdom Parliament would act only at the request and with the consent of Canada.

As Stephen Scott has noted, the settled convention regarding London amendments to the BNA Act was that a joint address by the Senate and House of Commons of Canada was both (1) a necessary and (2) a sufficient condition for action by the imperial Parliament for the exercise of its remaining legislative authority over Canada. ${ }^{54}$ The critical issue within Canada became the question of the extent of consent by the provincial governments required before the Canadian federal parliament applied to London for a constitutional change.

A White Paper, issued by the Canadian Federal Ministry of Justice in 1965, stated that as a general principle "the Canadian Parliament will not request an amendment directly affecting federal-provincial relationships without prior consultation and agreement with the provinces."55 The Paper went on to note, however, that the "nature and degree of provincial participation in the amending process . . . have not lent themselves to easy definition." 56

The pre-1982 amendment process for changes affecting federal-provincial relationships was thus defective in two respects. First, the process was ambiguous, in that it was unclear what degree of provincial consent was necessary to make legitimate a request by the federal parliament for constitutional change. As subsequent events in Canada have vividly demonstrated, a constitutional amendment process needs to be precise and unambiguous if true legitimacy is to attach to the fundamental law and to its revision. Secondly, the need to resort to the imperial Parliament for changes in basic Canadian law, however formal that process, was a symbolic vestige of colonialism.

The obvious solution was for Canadian authorities to agree upon a wholly domestic amendment formula, and to submit such a formula to the United Kingdom Parliament for enactment as the final London amendment to the BNA Act. This would confer full and final authority on Canadian domestic institutions over the Canadian Constitution and accomplish what has come to be known as "patriation" of the constitution.

The struggle to find an agreeable formula for patriating the Canadian Constitution contained two distinct elements, each relevant to a study of constitutional change:

53. British North America Act, 1949, 13 Geo. 6, ch. 81.

54. Scott, Opinion Submitted to the Foreign Affairs Committee of the House of Commons of the United Kingdom on the Role of the United Kingdom Parliament in Relation to the British North America Acts, 26 MCGILL L.J. 614, 615 (1981). See Scott, Law and Convention in the Patriation of the Canadian Constitution, 62 PARLIAMENTARIAN 183 (1981).

55. G. FaVreau, supra note 4, at 15.

56. Id. 
(1) the disagreement over the content of the future amendment formula, and

(2) the disagreement over the proper level of provincial consensus required for this last United Kingdom amendment-the one which would result in a new amendment formula for Canada.

The government of Canada and the governments of the ten provinces attempted unsuccessfully to reach agreement on a constitutional amendment formula in the course of ten federal-provincial conferences held in 1927, 1931, $1935,1950,1960,1964,1971,1978,1979$, and 1980.57 The assumption of these conferences seems to have been that a future amendment formula would be submitted to London for enactment only when it was agreed to by the federal government and the governments of all ten provinces. One distinguished scholar, writing in 1956, stated that although there was no certain degree of provincial consent necessary to make an application to London for more routine changes, it was "clear that an amendment providing for a general procedure of amendment will not be enacted without the consent of all the provinces." 58

After the federal-provincial conference of 1980 failed to reach unanimous agreement on any of the major issues, however, the federal government of Prime Minister Trudeau boldly introduced a joint resolution in the federal parliament to send to London a patriation package-with or without provincial agreement. ${ }^{59}$ The government's proposed resolution would ask the Queen to lay before the imperial Parliament a measure changing the BNA Act into the Constitution Act of Canada, with future power to amend that act in Canada, and including an entrenched Bill of Rights and a provision giving greater control over natural resources to the provinces. The premiers of eight of the ten provinces announced their opposition to the submission of this package to London. ${ }^{60}$ In significant measure, opposition was based upon the inclusion of a Charter of Rights which would limit the authority of provincial legislatures.

Although many provinces objected as well to the amendment part, which essentially gave a veto to Ontario and Quebec, it would likely have been possible to obtain provincial agreement on simple patriation with some compromise amendment formula. Since it would have been difficult to obtain future ratification of an entrenched Bill of Rights under any of the suggested domestic amendment formulas, however, the federal government insisted on treating patriation, an amendment formula, minority language rights, and an entrenched Charter of Rights (which Trudeau strongly favored) ${ }^{61}$ as a package.

Other papers in this volume will deal in some detail with the political and legal controversy created by these proposals; only a brief discussion is necessary here. For more than a year major controversy ensued in both Canada and England. In Canada the issue was the legality or propriety of the federal government's pro-

57. Reference Re Amendment of the Constitution of Canada, 125 D.L.R.3d 1, 103 (Can. 1981) (citing

G. Beaudoin, Le partage Des Pouvois, Edrtions de L'Université D'Ottawa 346 (1980).

58. W. LIVINGSTON, supra note 37 , at 105.

59. See The Globe and Mail (Toronto), Apr. 15, 1982, at 4, col. 1; see also id. at 5, col. 3 .

60. See The Globe and Mail (Toronto), Apr. 15, 1982, at 5, col. 3.

61. Id. at 10 , col. 1 . 
ceeding with a request to the United Kingdom Parliament for a fundamental change in the constitutional structure of Canada, when the request was opposed by eight of the ten provincial governments. In London, the issue was whether the United Kingdom Parliament should not even "sniff at the package" 62 before proceeding to automatic enactment, or whether that Parliament should "look behind" the anticipated legislative request from the Canadian federal government and take note of provincial opposition. ${ }^{63}$

In a proceeding brought by three of the opposing provinces, the constitutionality of proceeding with the request was challenged in the courts, and ultimately, in the Supreme Court of Canada. In Reference Re Amendment of the Constitution of Canada $^{64}$ the Court held, 7-2, that as a matter of strict law, there was no legally enforceable requirement that the concurrence of the provinces be obtained before the Canadian federal Parliament submitted its request to the United Kingdom .Parliament. ${ }^{65}$ This did not terminate the matter, however, for the Court went on to consider whether there was a custom "amounting to a convention of the constitution" that provincial consent be obtained. And the Court held 6-3 that there was indeed such a convention. ${ }^{66}$

The notion of a "convention" of the constitution is not a familiar one to American lawyers. "Conventions" in Canadian law are unwritten "rules of the constitution which are not enforced by the law courts," but which have been accepted over time by political institutions. ${ }^{67}$ A minority of three Justices found no basis for inferring the existence of the convention suggested by the provinces:

The degree of provincial participation in constitutional amendments has been a subject of lasting controversy in Canadian political life for generations. It cannot be asserted, in our opinion, that any view on this subject has become so clear and so broadly accepted as to constitute a constitutional convention. ${ }^{68}$

The majority of the Canadian Supreme Court, however, noted that no modern amendment had been requested by the federal government which limited the powers of the provinces without first obtaining provincial consent, and concluded that this practice had become a convention of the constitution. ${ }^{69}$ The Court declined to specify how much provincial concurrence was constitutionally (conventionally) required, noting only that the support of two of ten provinces was insufficient: "[I]t will be for the political actors, not this Court, to determine the degree of provincial consent required." 70

To one trained in American law, the most striking facet of the federal government's unsuccessful position in the Reference case was the irony of its twin arguments that (1) a reform which could not be accomplished by the Canadian

62. See Hogg, Commentaries: Amendment and Patriation, 19 Alta L. Rev. 369, 371 (1981).

63. Kershaw, The Canadian Constitution and the Foreign Affairs Commitlee of the U.K. House of Commons, 1980 and 1981, 62 Parlamentarian 173, 175 (1981).

64. 125 D.L.R. 3d 1 (Can. 1981).

65. Id. at 22 .

66. Id. at 89 .

67. P. HocG, supra note 3 , at 7 .

68. Reference Re Amendment of the Constitution of Canada, 125 D.L.R.3d 1, 115 (Can. 1981).

69. Id at 94,107 .

70. Id. at 103 . 
Parliament alone could be accomplished at its request by action of the imperial Parliament in London; and (2) action by the imperial Parliament, by settled convention, is a pure formality. No one suggested that the Canadian House of Commons and Senate could, acting alone, liberate Canada from the constraints of the BNA Act and enact a major reform of Canadian federalism. The 1949 amendment to the BNA Act, granting to the Canadian federal Parliament the authority to make constitutional changes "except as regards matters coming within the classes of subjects by this act assigned exclusively to the Legislatures of the provinces . . ."71 by express exception continued what was clear before: the federal legislature should not be permitted, on its own, to make constitutional changes affecting the provinces. But while conceding that the Canadian Parliament could not make these changes, the Trudeau government asserted that the unilateral submission to the United Kingdom Parliament was proper. Since the inhibition on unilateral action by the Canadian Parliament was based upon the very real consideration of the federal nature of Canada, it is difficult to see how an additional action (U.K. legislation) that the government itself argued was without substance could provide a suitable basis for constitutional reform. If the United Kingdom Parliament had retained "real" legislative discretion over Canada, then one could accept the notion that London could choose to do at Ottawa's request that which Ottawa could not do alone. The heart of Ottawa's argument in London, however, was that the U.K. Parliament was obligated, by settled convention, to rubber stamp without question whatever it received from the federal government of Canada. Trudeau's proposed procedure thus represented a triumph of form over substance, a resort to legal fiction that seems out of place in the process of constitutional revision.

And so it appeared to the majority of the Canadian Supreme Court. The constitutional convention inferred by the Court from past practice-that the Canadian Parliament will not seek from London an amendment directly affecting federal-provincial relationships without first securing the agreement of the provinces-was necessary to protect the basic federal principle of Canada, and to "prevent the anomaly that the [Canadian] House of Commons and Senate could obtain by simple resolutions what they could not validly accomplish by statute." 72

The Court's judgment was in the nature of an advisory opinion. There would have been no judicial interference if the federal government had proceeded unilaterally to submit its controversial package to London, and had sought automatic enactment by the U.K. Parliament. ${ }^{73}$

In the aftermath of the Court's declaration, however, an agreement was struck between the federal government and nine of the ten provinces. In exchange for provincial support, the federal government made several fundamental changes in its constitutional reform package, including (1) the addition of a provision permitting the legislature of a province to "override" provisions of the Charter of Rights by express declaration that a particular act would not be subject to the Charter,

71. British North America Act, 1949, 13 Geo. 6, ch. 81, § 1(1).

72. Reference Re Amendment of the Constitution of Canada, 125 D.L.R.3d 1, 106 (Can. 1981).

73. Id. at $48-49,84-85$. 
and (2) the substitution of an amendment formula preferred by most of the provinces. ${ }^{74}$

With support of nine provincial governments, the new constitution was sent, by Joint Address to the Queen, from the Canadian Parliament to London, where it was enacted by the British House of Commons by a vote of 334-44. The royal assent of the Queen was given on March 29, 1982. ${ }^{75}$ The ensuing royal pageant in Ottawa, which made the transfer of authority official, was boycotted by the Premier of Quebec who marched instead in a protest demonstration through the streets of Montreal. ${ }^{76}$

The government of Quebec alone continued to challenge the submission of the new compromise to London. Even if unanimity of the provinces was not required (the Canadian Supreme Court had spoken only of "substantial consent"), 77 Quebec argued in a new court challenge that its approval was essential since it represented a distinct society within Canadian federalism. ${ }^{78}$ The Quebec claim was unanimously rejected by the Quebec Court of Appeals a week before the patriation ceremony. ${ }^{79}$ The Quebec court noted that although "certain provinces are superior to others in land surface, population and resources, . . . legally speaking they are all on the same footing." The BNA Act, the court said, "give[s] the smaller provinces the same powers as the bigger provinces." 80

To what extent does the dissent of the Quebec government deprive the reformed constitution of legitimacy? As noted above, it was not thought appropriate in 1787 to bring under the authority of the new American Constitution any state which had not chosen to ratify. ${ }^{81}$ Quebec's objection means that the government of a province with one-fourth of Canada's people, the seat of its French and Catholic culture, did not agree to the reformed constitutional order of which it is now a part. Set against these concerns, however, are the following considerations.

First, the Quebec government's stated objections to the reformed constitution in its final form appear to be minor indeed, at least to one viewing from a distance. The provincial government of Quebec objected to a Charter of Rights which would limit its legislative authority; in its final version, however, the Charter can be overridden by a province under the authority of section 33, which provides that "the legislature of a province may expressly declare in an Act . . . that the Act or a provision thereof shall operate notwithstanding a provision included in [the principal sections] of this Charter."'82 Thus, none of these provisions need apply in Quebec so long as its legislature is willing expressly to declare them inapplicable.

Quebec objected as well to the amendment formula, but again on quite narrow

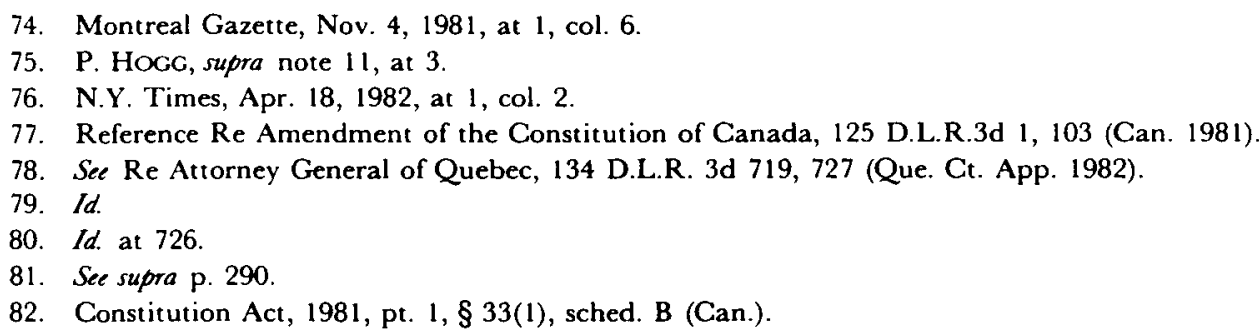


grounds. ${ }^{83}$ The final formula (as will be noted in greater detail below) permits any province whose legislature objects to an amendment approved by the federal government and seven provinces to "opt-out" of the amendment. ${ }^{84}$ Furthermore, if any amendment transfers educational or cultural responsibilities from the provinces to the federal government, a province which rejects the application of the amendment within its borders will be entitled to "reasonable compensation." 85 The Quebec government wanted "full" compensation and to have the provision apply to all amendments, not just those transferring educational or cultural matters.

Finally, Quebec objected to the provision relating to Minority Language Educational Rights, ${ }^{86}$ from which a province may not opt-out. The principal provision of this section, however, is declared by the Constitution Act to be ineffective in Quebec until the Quebec National Assembly by affirmative act chooses to have it apply. ${ }^{87}$ The remaining sections make only a minor incursion into Quebec's existing treatment of its Anglophone minority.

In sum, the fundamental provisions of the reformed constitution will continue to be those of the British North America Acts. Very little of substance in the revisions themselves will be applicable in Quebec without its consent. There was no guarantee, when the Canadian nation was formed in 1867, that the imperial Parliament would alter its BNA Act only with the consent of Quebec. If the agreement of nine of ten provinces and the federal parliament (including, it should be noted, almost all the Quebec representatives to that body) ${ }^{88}$ satisfies the federalist convention calling for provincial concurrence, Quebec's claim of illegitimacy does not seem substantial. The fundamental disagreement of Quebec's separatist provincial government may in fact be with the 1867 BNA Act itself, rather than with the recent reformation of the constitution.

\section{III}

\section{The Canadian Amendment Provisions: A Comparative}

\section{ASSESSMENT}

Perhaps as a reflection of the complex politics of Canadian federalism, the new domestic amendment procedures are unusually complicated. The basic structure includes the following provisions:

(1) A few parts of the constitution can be amended only with unanimous consent of the Canadian Parliament and the legislative assembly of every province. These provisions include the office of the Queen, the right of a province to a certain number of members in the House, the composition of the Canadian Supreme Court, and, significantly, any amendment of the Amendment Part itself; ${ }^{89}$

83. See The Globe and Mail (Toronto), Apr. 15, 1982, at 2, col. 5.

84. Constitution Act, 1981, pt. 5, $\S 38(3)$, sched. B (Can.).

85. Id. $§ 40$.

86. Constitution Act, 1981, pt. 1, § 23, sched. B (Can.).

87. Constitution Act, 1981, pt. 7, $\$ 59(2)$, sched. B (Can.).

88. Montreal Gazette, Dec. 3, 1981, at 1, col. 5.

89. Constitution Act, 1981 , pt. 5, § 41, sched. B (Can.). 
(2) Parliament acting alone can alter provisions relating to the executive government of Canada or to parliament itself, except with respect to those matters noted above which require unanimous consent, and certain other fundamental provisions, such as the principle of proportionate representation of the provinces in the House of Commons; 90

(3) The legislative assembly of a province may alter its own provincial constitution, except for those few matters noted above which require unanimous consent; ${ }^{91}$ and

(4) The amendment of any provision that applies to one or more, but not all, provinces may be made upon the agreement of the federal parliament and each province to which the amendment applies. ${ }^{92}$

Each of the provisions noted above deals with special situations. The basic amendment provision applicable to most amendments will be a version of the "Vancouver formula."93 Under this basic provision, an amendment may be made upon the concurrence of the Senate and House of Commons, and the legislative assemblies of two-thirds of the provinces that have, in the aggregate, at least fifty percent of the population of all the provinces. ${ }^{94}$ Where an amendment derogates from the rights of a province, it must be passed by the House and Senate, and in the requisite number of legislative assemblies, by a majority of the members rather than by a mere majority of those present and voting. ${ }^{95}$ Any amendment requiring the assent of the appointed federal Senate can be passed without the consent of that body, if repassed by the House of Commons after 180 days have elapsed. ${ }^{96}$ Unlike the discarded "Victoria formula" under which Ontario and Quebec would each have had a permanent veto over amendments to the constitution, the new provisions grant to no single province the special status of a veto.

Perhaps the most interesting provision of the Amendment Part, however, is section 38(3) which states that any amendment which derogates from the proprietary rights of a province, or from the legislative or governmental powers of a province "shall not have effect in a province the legislative assembly of which has expressed its dissent by resolution adopted by a majority of its members prior to proclamation of the amendment."97 The possible ramifications of this provision will be considered below.

An evaluation of the Canadian amendment procedures should perhaps begin by noting that its detailed provisions answer several perplexing questions that Article $\mathrm{V}$ of the American Constitution has left to speculation and, more recently, controversy. Article V confers upon Congress the power to propose amendments, and upon the states the power to ratify. It is silent, however, as to how long an

90. Id. $\S 44$.

91. Id. $\S 45$.

92. Id. § 43 .

93. See McConnell, Custing the Gordian Knot: The Amending Pracess in Canada, LaW \& Contemp. Probs., Summer 1981, at 195, 214-15.

94. Constitution Act, 1981 , pt. $5, \S 38(1)$, sched. B (Can.).

95. Id. §38(2).

96. Id. § $47(1)$.

97. Id. $\S 38(3)$. 
unratified amendment remains viable, and as to whether a state which has ratified an amendment may subsequently change its mind and rescind its ratification. In Dillon v. Gloss ${ }^{98}$ the Supreme Court held that Congress had the implicit power to set a time limit for the consideration of an amendment by the states. Left unanswered in Dillon was whether Congress could subsequently extend that time, as Congress undertook to do as the proposed Equal Rights Amendment neared its original seven year deadline. ${ }^{99}$ Consideration of the Equal Rights Amendment has been further complicated by the purported rescission by several previously ratifying states. ${ }^{100}$ Particularly perplexing is the fact that there appears at present to be no definitive mechanism for ascertaining the validity of time extensions or rescissions. And however these questions should be resolved, their mere existence casts a substantial cloud over the amendment process, and threatens to deny a proper sense of legitimacy to future amendments.

Part V of the Canadian Constitution Act has the virtue of answering these questions. Amendments may be initiated by either a provincial government or the national parliament. Once initiated, an amendment remains open for ratification, or dissent from the application of the amendment within a province, for at least a year, unless before that time every province has adopted a resolution of assent or dissent. ${ }^{101}$ A proposed amendment lapses unless ratified by the requisite number of assemblies within three years of the adoption of the resolution which initiated the amendment procedure. ${ }^{102}$

The Canadian provision clearly endorses the concept of rescission: "A resolution of assent made for the purposes of this Part may be revoked at any time before the issue of a proclamation authorized by it."103 Similarly, a province which has dissented from the application of a proposed amendment may reverse itself and assent to the amendment. ${ }^{104}$ Even after proclamation of a new amendment, a previously dissenting province may decide to accept the amendment and have it apply within the province. ${ }^{105}$ Once a province has assented to an amendment, however, and the amendment has been proclaimed, that province may not thereafter "opt-out" of application of the amendment. No provision, at least, is made for such a reversal after adoption of an amendment and assent by a province; in light of the explicit treatment of all similar issues, silence in this instance is best construed as a denial of power.

The Canadian Constitution also avoids what appears to be a philosophical conundrum under the American amendment process. ${ }^{106}$ A proviso to Article V states that no state shall be deprived of its equal suffrage in the Senate without its consent. Can this be amended? That is, could three-fourths of the states first

98. 256 U.S. $368,373,376$ (1920).

99. H.R.J. Res. 638, 95th Cong., 2d Sess., 92 Stat. 3799 (1978).

100. See Idaho v. Freeman, 529 F. Supp. 1107,1114 (D. Idaho 1981), appeal pend'g sub nom. National Org. for Women, Inc. v. Idaho, 102 S. Ct. 1272 (1982).

101. Constitution Act, 1981, pt. 5, § 39(1), sched. B (Can.).

102. Id. $\S 39(2)$.

103. Id. $\$ 46(2)$.

104. Id. $\S 38(3)$.

105. Id. $\S 38(4)$.

106. See Linder, What in the Constitution Cannot Be Amended?, 23 ARIZ. L. REV. 717 (1981). 
amend Article $\mathrm{V}$ by deleting this proviso, and then by three-fourths deprive some states, without their consent, of equal representation in the Senate? Could it be done in one step? Or is it implicit that the equal suffrage provision, which requires the consent of every adversely affected state, is not subject to amendment under Article V? Canada now answers these and similar questions by providing that the Amendment Part is itself unamendable-except with the concurrence of every province and the federal parliament. ${ }^{107}$ The amendment clause thus provides special protection to certain very fundamental matters, such as the office of the Queen, by first providing, in its Amendment Part, for revision of such basic norms only by unanimous consent, and then by locking in this safeguard by rendering the amendment process itself subject to change only by unanimous agreement.

In one major respect, however, the Canadian Constitution seems unduly rigid. It affords little or no possibility of reforming those existing institutions of government which play a critical role in the amendment process. No amendment of any kind can be enacted, for example, without the concurrence of the Canadian House of Commons. This precludes any reform of that institution not desired by its members. Moreover, in a system of parliamentary government, it effectively precludes any amendment not approved by the Prime Minister. The concurrence of seven provincial assemblies is also required, which again, under parliamentary government, means that the concurrence of the provincial premiers is an essential step to every reform.

The central role of existing institutional bodies in the amendment process will serve to narrow substantially the range of future constitutional discourse. No future reform of provincial government which runs counter to the vested interest of the existing institutions is conceivable. One way to have avoided the permanent roadblock of existing legislative assemblies would have been to provide for ratification by referendum, as is done in Switzerland and Australia, ${ }^{108}$ requiring, for example, a majority vote in seven of ten provinces, as well as a national majority, for enactment of an amendment. As an alternative to referenda, the American approach of ratification by specially elected conventions in every province might have been considered. ${ }^{109}$ Unlike a referendum, a convention offers the possibility of being a deliberative body. It is not affected, moreover, by institutional selfinterest, and since its members are elected for the express purpose of approving or disapproving a proposed amendment, there is substantial popular input into its determination. ${ }^{110}$ (The one American experience with ratification by conventions, rather than by state legislatures, came in 1933. The twenty-first amendment, which repealed prohibition, was sent to, and ratified by, conventions in each state.

107. Constitution Act, 1981, pt. 5, §41(e), sched. B (Can.).

108. See W. Livingston, supra note 37 , at 319-22.

109. Article $\mathrm{V}$ of the Constitution provides that an amendment proposed by Congress "shall be valid to all Intents and Purposes, as Part of this Constitution, when ratified by the Legislatures of three fourths of the several States, or by Conventions in three fourths thereof, as the one or the other Mode of Ratification may be proposed by the Congress." U.S. ConsT. art. V (emphasis added). The Supreme Court held in United States v. Sprague, 282 U.S. 716, 730 (1931), that "The choice . . . of the mode of ratification, lies in the sole discretion of Congress."

110. See Dellinger, Another Route to the ERA, NEWSWEEk, Aug. 2, 1982, at 8. 
In that instance, there was very little deliberation. The state conventions met and quickly endorsed the preferences of the voters who had selected delegates on the basis of whether a particular candidate favored ratification or rejection of that one proposal.) ${ }^{111}$ Since the Canadian Amendment Part can itself be amended only by agreement of the national government and every legislative assembly, any reform of those institutions seems effectively precluded. ${ }^{112}$

Some have hoped to see in the reformed Canadian Constitution an occasion for national renewal and a reversal of the centrifugal forces at work in Canada. ${ }^{13}$ In some respects the Constitution Act may indeed exert a positive force for Canadian nationalism. A Charter of Rights, even though it may be overridden by a provincial assembly determined to do so, nonetheless articulates a set of rights to which Canada aspires for its citizens and which are national rights that one has as a Canadian. Mobility and minority education rights, though less complete than some wished, likewise set forth aspirations that there be one Canada in which every Canadian can feel welcome.

Casting a shadow over the reformed constitution, however, is the critical section permitting dissenting provincial governments to preclude the application within their borders of future amendments to the constitution. ${ }^{114}$ Long opposed by Trudeau as a measure which would lead to a "checkerboard constitution" and foster national disintegration, the opting-out provision will, at a minimum, preclude future amendments which might have permitted evolving Canadian principles to be applied throughout the country.

As one reviews the twenty-six amendments to the American Constitution, it is interesting to consider what impact such a provision would have had. It would not have precluded the Bill of Rights ${ }^{15}$ in its initial application to the federal government alone, nor the amendment limiting the President to two terms, ${ }^{116}$ nor that which established rules for presidential succession. ${ }^{17}$ Almost all of the other amendments, however, have at least in part served the function of bringing an evolving national consensus to bear upon a section or states which were not in step with that consensus. Several had meaningful application only in states which would have exempted themselves had they had the opportunity: the thirteenth amendment, ${ }^{118}$ abolishing slavery, is the most profound example; the twentyfourth, ${ }^{119}$ abolishing a poll tax used only in a few non-ratifying states, is another. The fourteenth amendment, ${ }^{120}$ which sought to guarantee equality of rights to

111. For a compilation of the records of the state conventions ratifying the 21 st amendment, see E. Brown, Ratification of the TWenty-First Amendment to The Constitution of The United STATES (1938).

112. For the suggestion that Canada should utilize the process of initiative and referendum in the amendment process, see Hogg, The Theory and Practice of Constitutional Reform, 19 ALTA. L. REV. 335, 349-51 (1981).

113. See, e.g., The Task Force on Canadian Unity, A Future Together (1979) at 17.

114. Constitution Act, 1981 , pt. 5, \& 38(3), sched. B (Can.).

115. U.S. CONST. amends. I-X.

116. Id. amend. XXII.

117. Id. amend. XXV.

118. Id amend. XIII.

119. Id amend. XXIV.

120. Id. amend. XIV. 
freedmen, imposed national standards on a subcommunity. Without it, it is difficult to imagine the full integration of the South into the national economy. The termination, through a nationally imposed amendment, of the South's extreme racial conflict has been a necessary precondition to its economic ascendency. Prohibition, ${ }^{121}$ women's suffrage, ${ }^{122}$ and the proposed Equal Rights Amendment, while less striking examples, have nonetheless had in part the function of applying a national consensus to areas of dissent from that consensus. The ability to apply amendments to dissenting states has thus played a significant role in the evolution of a sense of America as a single nation.

The provision permitting a province to "opt-out" of an amendment functions in some respects like a provision requiring unanimous consent for amendments. The preservation of federalism requires, of course, that the provinces or states have some critical role to play in any amendment process. The requirement of unanimity, however, is one more closely associated with confederacies than with federal systems.

As Professor Livingston reminds us, the formal institutions of federalism "are only the surface manifestations of the deeper federal quality of the society" which subtends them. ${ }^{123}$ The inescapable fact is that Canada is a society of weak national loyalties, described by one observer as "almost totally lacking in a genuinely shared set of symbols, heroes, historical incidents, enemies, or even ambitions." 124 An amendment process which reflects the decentralized quality of such a society is neither good nor bad. It is only accurate.

121. Id amend. XVIII (1787, repealed 1933).

122. Id. amend. XIX.

123. W. LIVINGSTON, supra note 37, at 2.

124. Meisel, Canadian Parties and Politics, in Contemporary CaNAda 135 (R. Leach ed. 1968), quoted in A. Lijphart, Democracy in Plural Societies 128 (1977). 